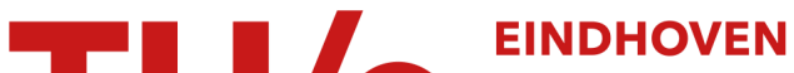 UNIVERSITY OF TECHNOLOGY
}

\section{Time resolved measurements of streamer inception in air}

\section{Citation for published version (APA):}

Briels, T. M. P., Veldhuizen, van, E. M., \& Ebert, U. M. (2008). Time resolved measurements of streamer inception in air. IEEE Transactions on Plasma Science, 36(4), 908-909.

https://doi.org/10.1109/TPS.2008.920223

DOI:

10.1109/TPS.2008.920223

Document status and date:

Published: 01/01/2008

\section{Document Version:}

Publisher's PDF, also known as Version of Record (includes final page, issue and volume numbers)

\section{Please check the document version of this publication:}

- A submitted manuscript is the version of the article upon submission and before peer-review. There can be important differences between the submitted version and the official published version of record. People interested in the research are advised to contact the author for the final version of the publication, or visit the $\mathrm{DOI}$ to the publisher's website.

- The final author version and the galley proof are versions of the publication after peer review.

- The final published version features the final layout of the paper including the volume, issue and page numbers.

Link to publication

\section{General rights}

Copyright and moral rights for the publications made accessible in the public portal are retained by the authors and/or other copyright owners and it is a condition of accessing publications that users recognise and abide by the legal requirements associated with these rights.

- Users may download and print one copy of any publication from the public portal for the purpose of private study or research.

- You may not further distribute the material or use it for any profit-making activity or commercial gain

- You may freely distribute the URL identifying the publication in the public portal.

If the publication is distributed under the terms of Article 25fa of the Dutch Copyright Act, indicated by the "Taverne" license above, please follow below link for the End User Agreement:

www.tue.nl/taverne

Take down policy

If you believe that this document breaches copyright please contact us at:

openaccess@tue.nl

providing details and we will investigate your claim. 


\title{
Time Resolved Measurements of Streamer Inception in Air
}

\author{
T. M. P. Briels, E. M. van Veldhuizen, and U. Ebert
}

\begin{abstract}
Images show how an ionization cloud forms at the needle electrode, how the cloud evolves into a shell, and how one or more streamers emerge from this shell and propagate.
\end{abstract}

Index Terms-Gas discharges, pulsed corona, streamer inception, streamer propagation.

$\mathbf{S}$ TREAMERS are narrow rapidly growing ionized channels that generally emerge from sharp tips when a high voltage is applied. Streamers prepare the path of sparks of all sizes. They are used in industry, e.g., in gas and water cleaning [1], [2]. They also can be observed as so-called sprite discharges at low pressure in the atmosphere at 40 to $90 \mathrm{~km}$ altitude [3].

As the rapid growth of streamers is dominated by fast two-body-collisions, theory predicts approximate similarity between streamers at different pressures, and experiments confirm it [4]. Similarity implies that time and length scales approximately scale like $1 / p[2]-[4]$; therefore, one can zoom into the streamer evolution by lowering the pressure $p$.

In Fig. 1, we image/illustrate the early stages of evolution of positive streamers at pressures of 100 and 400 mbar, with applied voltage ranging from 7.5 to $25 \mathrm{kV}$. The discharges start with an ionization cloud at the anode tip and evolve downwards toward the cathode plate at a distance of $40 \mathrm{~mm}$. The discharges are driven by single high-voltage pulses with a short rise time of $25 \mathrm{~ns}$. These pulses are created with a capacitor supply (the C-supply described in [5]) using a semiconductor switch. One picture is taken per discharge pulse using a digital Andor iCCDcamera. The false colors in the images indicate the intensity of the light; in each panel, they are adjusted to resolve the structure optimally. The time $T$ below each panel in the figure is the delay between the start of the corona current and the opening of the camera. T has a jitter of about $30 \mathrm{~ns}$ which is visible when comparing panels Ia and Ib or IIIc and IIId. The exposure duration is given by $\Delta t$.

The figures show the formation of an initial ionization cloud at the anode tip (panels Ia, IIa, IIIa). The cloud expands and forms a shell (Ib, IIIb), i.e., the maximal light intensity moves away from the tip. The shell destabilizes and forms one or

Manuscript received November 26, 2007; revised February 15, 2008. This work was supported by the Technologiestichting STW and Nederlandse Organisatie voor Wetenschappelijk Onderzoek (NWO).

T. M. P. Briels and E. M. van Veldhuizen are with the Department of Applied Physics, Eindhoven University of Technology, 5600 MB Eindhoven, The Netherlands (e-mail: e.m.v.veldhuizen@tue.nl).

U. Ebert is with the Department of Applied Physics, Eindhoven University of Technology, 5600 MB Eindhoven, The Netherlands and also with the Center for Mathematics and Computer Science, 1090 GB Amsterdam, The Netherlands.

Digital Object Identifier 10.1109/TPS.2008.920223 more streamers (e.g., Ic, IIb, IIIb) that propagate toward the plate electrode (e.g., Id, IIc, IIIc, IIId). Panel IId shows the reillumination of the streamers close to the tip. A tiny anode glow is also visible in IIId. Positive and negative discharges generally evolve in the same way. However, in the present electrode configuration and at 1 bar, positive discharges emerge above a voltage of $5 \mathrm{kV}$, while negative discharges emerge only above $40 \mathrm{kV}$ (which is about the dc-breakdown voltage of our $40 \mathrm{~mm}$ gap) [6]. Future theory should try relating these different inception voltages to the different nucleation processes of the ionization cloud at the anode or cathode tip.

The first and the second column show discharges at the same pressure of $100 \mathrm{mbar}$, but at a voltage of $10 \mathrm{kV}$ in column I versus $7.5 \mathrm{kV}$ in column II. At $10 \mathrm{kV}$, the initial ionization cloud has a reduced height of $p \cdot h=1.9 \pm 0.4 \mathrm{~mm} \cdot \mathrm{bar}$, while for the lower voltage of $7.5 \mathrm{kV}$, it is $p \cdot h=0.9 \pm 0.4 \mathrm{~mm} \cdot$ bar, i.e., only half as high. For $10 \mathrm{kV}$, only one streamer with reduced diameter $p \cdot d \approx 0.25 \mathrm{~mm} \cdot$ bar (panel Id) hardly emerges from the cloud before reaching the electrode, while for $7.5 \mathrm{kV}$, four streamers with $p \cdot d \approx 0.16 \mathrm{~mm} \cdot$ bar (IIb) emerge and propagate. They are all thin streamers of type 3 in the classification of [4], where the streamer diameter was discussed as a function of voltage and voltage rise time.

The second and the third column look similar, but the pressure in column III is as high as 400 mbar and the voltage is $25 \mathrm{kV}$. The reduced height of the cloud $p \cdot h=3.8 \pm 1.6 \mathrm{~mm}$. bar is actually twice as large as in column I. The reduced streamer diameter is $p \cdot d \approx 0.6 \pm 0.1 \mathrm{~mm} \cdot \operatorname{bar}$ (IIIc, IIId), four times thicker than the streamers in column II. This diameter was classified as type 2 in [4]. Comparable measurements in synthetic air [7] show that for $U=40 \mathrm{kV}, p=613$ mbar, a discharge gap length of $30 \mathrm{~mm}$, and a voltage rise time of $11 \mathrm{~ns}$, a single streamer as thick as the cloud propagates toward the plate.

\section{REFERENCES}

[1] E. M. van Veldhuizen, Ed., Electrical Discharges for Environmental Purposes. Huntington, NY: Nova, 2000.

[2] U. Ebert et al., Plasma Sources Sci. Technol., vol. 17, p. S118, 2006.

[3] V. P. Pasko, "Red sprite discharges in the atmosphere at high altitude: the molecular physics and the similarity with laboratory discharges," Plasma Sources Sci. Technol., vol. 16, no. 1, pp. S13-S29, Feb. 2007.

[4] T. M. P. Briels, E. M. van Veldhuizen, and U. Ebert, "Positive Streamers in Air and Nitrogen," J. Phys. D, Appl. Phys. submitted for publication.

[5] T. M. P. Briels et al., "Circuit dependence of the diameter of pulsed positive streamers in air," J. Phys. D, Appl. Phys., vol. 39, no. 24, pp. 5201-5210, Dec. 2006.

[6] T. M. P. Briels, J. Kos, G. J. J. Winands, E. M. van Veldhuizen, and U. Ebert, "Positive and Negative Streamers," J. Phys. D, Appl. Phys. submitted for publication.

[7] M. M. Nudnova and A. Yu. Starikovskii“"Development of streamer flash initiated by HV pulse with nanosecond rise time," IEEE Trans. Plasma Sci., vol. 36, no. 3, Jun. 2008. 


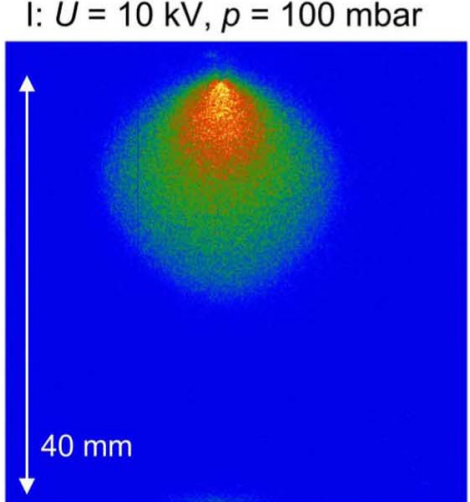

(a) $\mathrm{T}=0 \mathrm{~ns}, \Delta \mathrm{t}=100 \mathrm{~ns}$

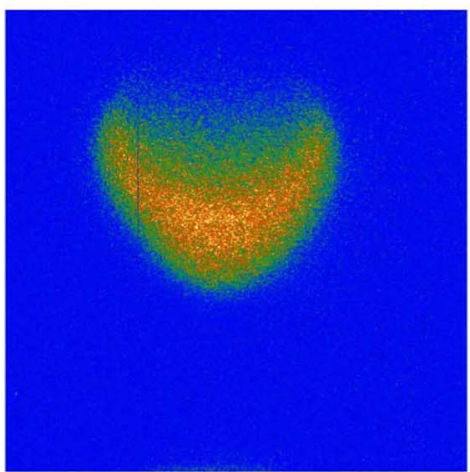

(b) $\mathrm{T}=50 \mathrm{~ns}, \Delta \mathrm{t}=50 \mathrm{~ns}$

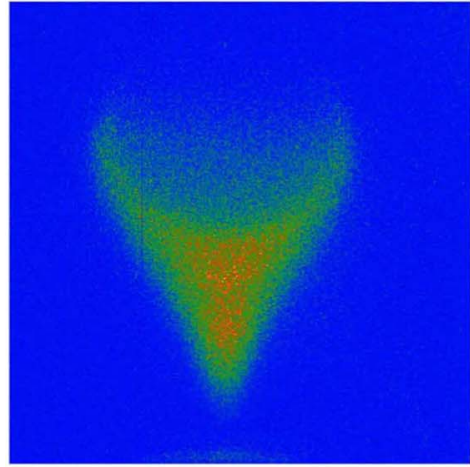

(c) $\mathrm{T}=100 \mathrm{~ns}, \Delta \mathrm{t}=50 \mathrm{~ns}$

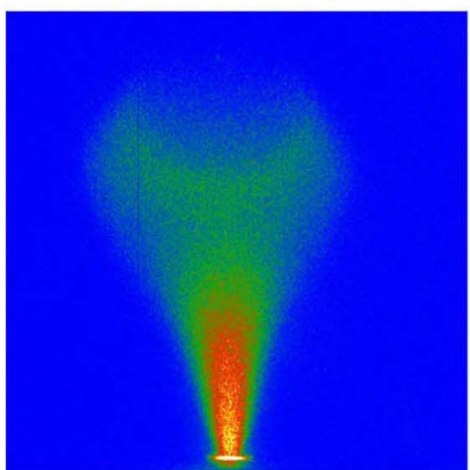

(d) $\mathrm{T}=100 \mathrm{~ns}, \Delta \mathrm{t}=100 \mathrm{~ns}$

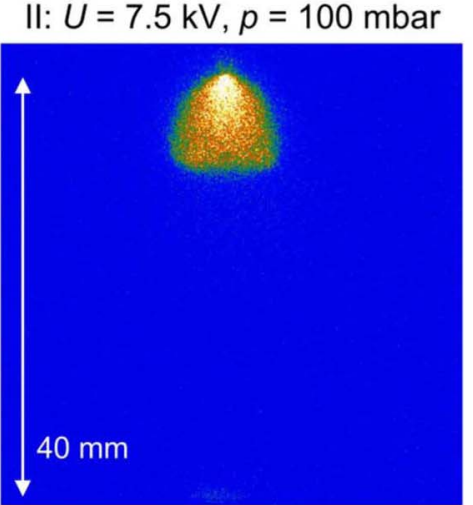

(a) $\mathrm{T}=0 \mathrm{~ns}, \Delta \mathrm{t}=200 \mathrm{~ns}$

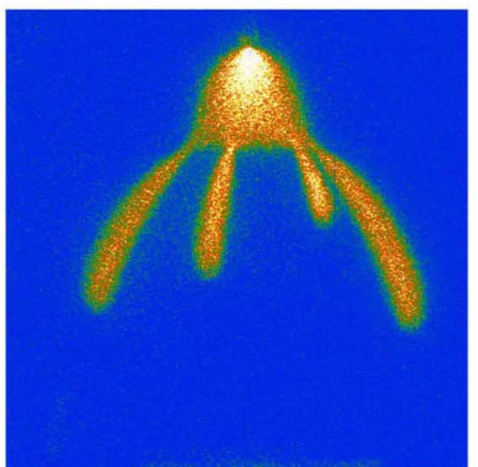

(b) T = $0 \mathrm{~ns}, \Delta \mathrm{t}=300 \mathrm{~ns}$

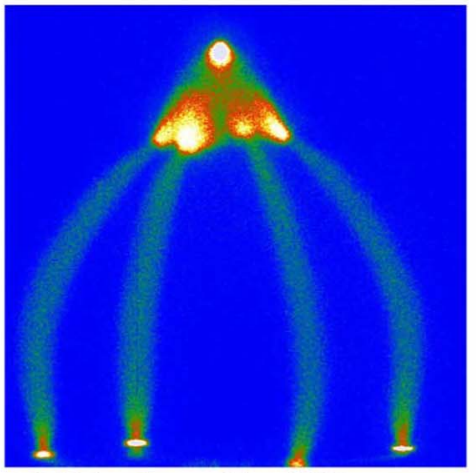

(c) T $=0 \mathrm{~ns}, \Delta \mathrm{t}=500 \mathrm{~ns}$

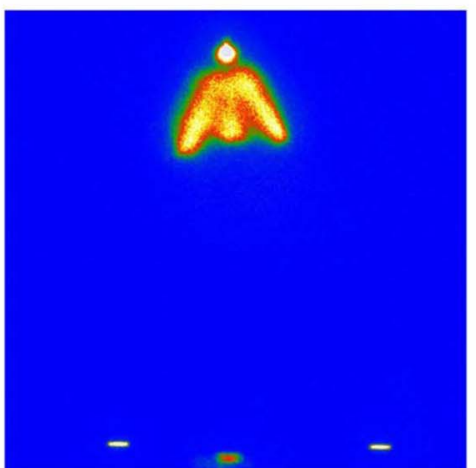

(d) $\mathrm{T}=500 \mathrm{~ns}, \Delta \mathrm{t}=500 \mathrm{~ns}$

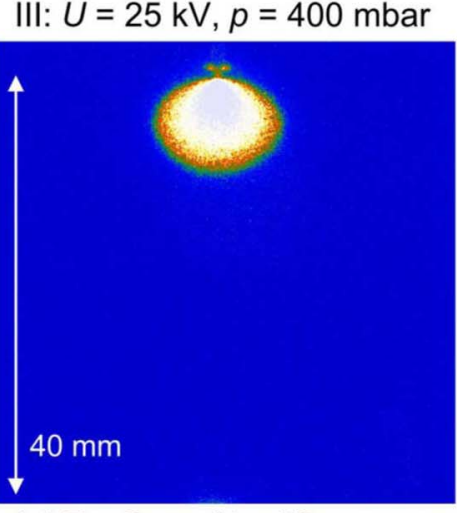

(a) $\mathrm{T}=0 \mathrm{~ns}, \Delta \mathrm{t}=50 \mathrm{~ns}$

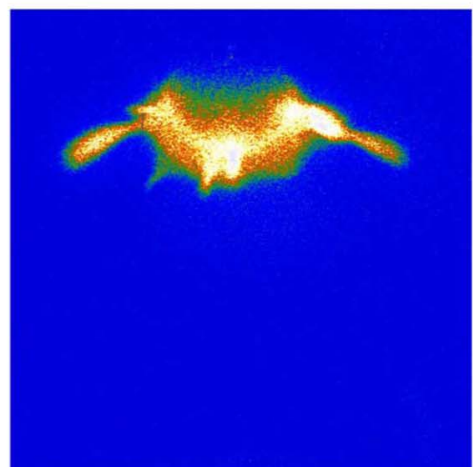

(b) T = $50 \mathrm{~ns}, \Delta \mathrm{t}=50 \mathrm{~ns}$

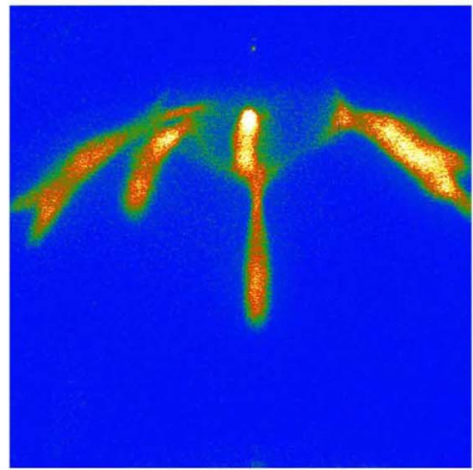

(c) $\mathrm{T}=125 \mathrm{~ns}, \Delta \mathrm{t}=50 \mathrm{~ns}$

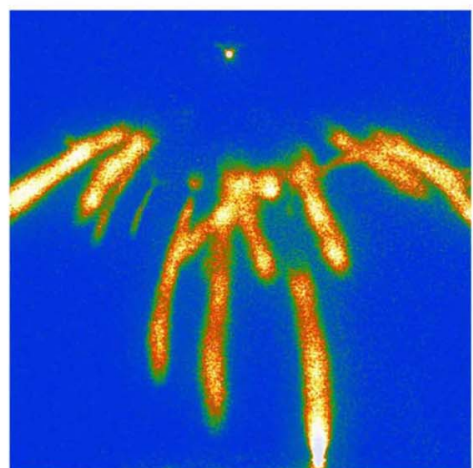

(d) $\mathrm{T}=125 \mathrm{~ns}, \Delta \mathrm{t}=50 \mathrm{~ns}$

Fig. 1. Series of time resolved photographs showing stages of evolution of positive discharges in air. The electrodes are (above) point to (below) plane with a distance of $40 \mathrm{~mm}$. Columns I and II show the same pressure of $p=100 \mathrm{mbar}$, but different applied voltages (I: $10 \mathrm{kV}$, II: $7.5 \mathrm{kV}$ ), column III is at higher pressure $p=400 \mathrm{mbar}$ and an applied voltage of $25 \mathrm{kV}$. The exposure times are indicated with $T$ for the start and $\Delta t$ for the duration. 